EDYTA CHLEBOWSKA

ORCID: 0000-0001-7814-6323

\title{
CASTRA ANNIBALIS
}

Akwarela Castra Annibalis należała dotychczas do pokaźnego korpusu prac plastycznych Norwida, które były wprawdzie notowane w literaturze przedmiotu, ale nie zostały nigdy opublikowane, w związku z czym wiedza na ich temat pozostawała w istotnym stopniu ograniczona. Praca ta została najpełniej omówiona w jednej z publikacji towarzyszących pierwszej, a zarazem największej jak dotąd wystawie monograficznej, prezentującej życie i twórczość Cypriana Norwida, zorganizowanej przez Muzeum Narodowe w Warszawie w 125. rocznicę urodzin poety. Wystawa była eksponowana w gmachu warszawskiego muzeum od 20 grudnia 1946 r. do 9 maja 1947 roku, a następnie - jako wystawa objazdowa - odwiedziła kolejno: Miejską Galerię Sztuk Plastycznych w Łodzi (11 maja 2 czerwca 1847), Muzeum Wielkopolskie w Poznaniu (9 czerwca - 6 lipca 1847) oraz Towarzystwo Przyjaciół Sztuk Pięknych w Krakowie (28 września - 26 października 1947). Ekspozycji towarzyszył obszerny katalog, przynoszący informacje na temat blisko 600 eksponatów, pośród których najobszerniej reprezentowana była twórczość artystyczna Norwida (niemal 400 obiektów) oraz dokumenty odnoszące się do biografii poety (155 pozycji), następnie twórczość literacka (70 obiektów) oraz materiały pochodzące z ,pracowni norwidowskiej” Zenona Przesmyckiego (ponad 50 obiektów) ${ }^{1}$. Poznańska edycja wystawy została uzupełniona o szereg eksponatów, pochodzących z Muzeum Wielkopolskiego, Biblioteki Fundacji Kórnickiej, Seminarium Historii Literatury Polskiej Uniwersytetu Poznańskiego i z kolekcji prywatnych oraz o zbiór opracowań norwidologicznych powstałych w kręgu wielkopolskich badaczy. Pełne zestawienie obiektów dołączonych do głównego korpusu wystawy i eksponowanych wyłącznie w jej

${ }^{1}$ Cyprian Norwid. Wystawa w 125 rocznice urodzin. Katalog, Muzeum Narodowe w Warszawie, Warszawa 1946, ss. 132, 12 il. 
poznańskiej odsłonie opublikowała na łamach „Kroniki Miasta Poznania” Joanna Eckhardtówna ${ }^{2}$. Katalog „,norwidianów wielkopolskich” został podzielony na kilka działów: I. Życie Norwida, II. Listy Norwida, III. Prace artystyczne Norwida, IV. Pierwodruki, V. Prace o Norwidzie (a. drukowane, b. niedrukowane). W zestawieniu prac artystycznych znalazły się dwie ryciny: Paciorek dziecka (właśc. Parabola o świecy pod korcem) i Święty Józef z Dzieciątkiem, ponadto rysunek Głowa starca oraz interesująca nas akwarela Castra Annibalis. Praca ta stanowiła wówczas własność profesora Romana Pollaka, który był zarazem czynnie zaangażowany w przygotowanie ekspozycji poznańskiej. Wraz ze swymi współpracownikami z Zakładu Historii Literatury Polskiej Uniwersytetu Poznańskiego prof. Pollak odpowiedzialny był za zgromadzenie wszystkich eksponatów, które dopełniły wielkopolską edycję Norwidowskiej wystawy.

W katalogowej nocie dotyczącej omawianej akwareli Eckhardtówna zawarła ogólny opis kompozycji z uwzględnieniem wszystkich odautorskich napisów, dopełniony informacjami dotyczącymi techniki wykonania i wymiarów pracy, oraz wskazaniem właściciela obiektu. W późniejszej literaturze przedmiotu $\mathrm{Ca}$ stra Annibalis wzmiankowany był jedynie w kilku przekrojowych opracowaniach, kierujących się zasadą dokumentalistycznej akrybii. Juliusz W. Gomulicki umieścił akwarelę w tabeli przynoszącej chronologiczny rejestr , artystycznych utworów" Norwida, zamieszczonej w ostatnim tomie edycji Pism wszystkich poety ${ }^{3}$, a Aleksandra Melbechowska-Luty w monografii poświęconej plastycznej twórczości autora Echa ruin wymieniła kompozycję wśród prac odnoszących się do tradycji antycznej. ${ }^{4}$ Wreszcie na kartach Kalendarza życia i twórczości Cypriana Norwida akwarela została odnotowana w zestawieniu prac plastycznych powstałych w 1850 roku. ${ }^{5}$ Nad wyraz skromna obecność Castra Annibalis w literaturze przedmiotu wydaje się w pełni zrozumiała w kontekście braku wizualnej dokumentacji kompozycji, czy to w formie fotografii, czy też stosownej, choćby czarno-białej reprodukcji.

2 J. EcKhardtówna, Norwidiana wielkopolskie, „Kronika miasta Poznania”, XX: 1947, nr 2/3, s. 172-177.

3 PWsz XI, 229.

${ }^{4}$ A. Melbechowska-Luty, Sztukmistrz. Twórczość artystyczna i myśl o sztuce Cypriana Norwida, Warszawa 2001, s. 159.

5 Z. Trojanowiczowa, Z. DAmbeK, przy współudziale J. CZARnomorskiej, Kalendarz życia i twórczości Cypriana Norwida, t. I: 1821-1860, Poznań 2007, s. 418. 


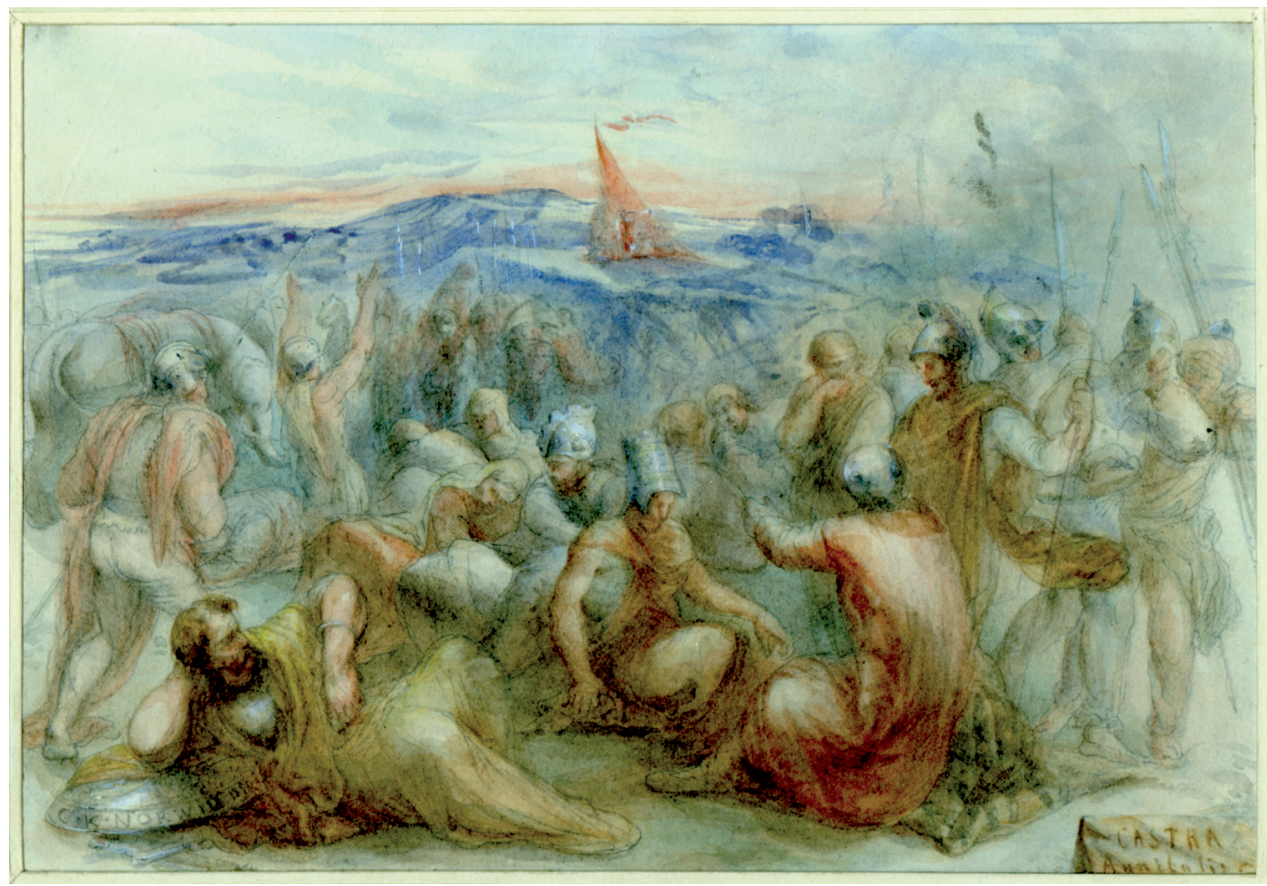

C. Norwid, Castra Annibalis, 1850, akwarela, papier; kolekcja prywatna

Niniejsza publikacja akwareli Castra Annibalis, przypadająca w roku kolejnego znaczącego jubileuszu urodzin Norwida, umożliwia wypełnienie dotychczasowej luki w obrazie plastycznej spuścizny twórcy Solo. Obiekt w dalszym ciągu pozostaje w rękach prywatnych i to właśnie dzięki uprzejmości obecnych właścicieli możemy zapoznać się naocznie z pracą, która była dotychczas znana wyłącznie z krótkiego katalogowego opisu Eckhardtówny. Jest to akwarelowa kompozycja na szkicu ołówkowym, wykonana na białym papierze, oprawiona we współczesną ramę. Wymiary pracy w świetle passe-partout wynoszą $14 \times 19,5 \mathrm{~cm} .{ }^{6}$ Ołówkowy szkic stanowi istotny element przedstawienia, jest widoczny w obrębie całej kompozycji, a w wielu partiach został jedynie lekko podmalowany przejrzystą akwarelową plamą. Tym niemniej rysunek ma charakter sumaryczny, oszczędny, wykreśla jedynie główne zarysy przedstawianych postaci, jeszcze bardziej sygnalnie zaznaczając elementy scenerii w jakiej rozgrywa się

${ }^{6}$ Wymiary podane przez Eckhardtówną $(14,8 \times 19,5 \mathrm{~cm})$ nieznacznie się różnią od wymiarów rzeczywistych. Niewykluczone, że kustosz Muzeum Wielkopolskiego mierzyła akwarelę bez oprawy. 
prezentowana scena figuralna. W związku z tym, że praca ma charakter wybitnie szkicowy poświęcę nieco więcej uwagi opisowi przedstawienia.

Zgodnie z tytułem wpisanym w obrębie akwareli, Castra Annibalis ukazuje fragment wojskowego obozu armii Hannibala usytuowanego na tle górzystego pejzażu. Na niebie czerwienieje łuna wschodzącego słońca, w świetle którego żołnierze zdają się szykować do opuszczenia miejsca nocnego odpoczynku. Centrum kompozycji wypełnia kilka osób siedzących lub leżących na ziemi, wokół których trwa ożywiony ruch uzbrojonych oddziałów. Po lewej, wsparty prawym ramieniem na tarczy unosi się z pozycji leżącej brodaty mężczyzna w sile wieku ubrany w luźno udrapowaną szatę. Towarzyszą mu dwaj żołnierze siedzący naprzeciwko siebie na ziemi, w purpurowo-brunatnych płaszczach i w hełmach. Jeden, widziany od tyłu zwraca się do stojącego po prawej stronie żołnierza, wskazując lewą dłonią w głąb sceny. Stojący żołnierz trzyma w lewej dłoni włócznię wspartą o ziemię, na głowie ma hełm z grzebieniem. Za jego plecami zarysowują się sylwetki kolejnych uzbrojonych żołnierzy. W pierwszoplanowej grupie, poza trzema wymienionymi postaciami widzimy kilka osób, które zdają się budzić ze snu, wśród nich można dostrzec kobietę z głową okrytą welonem. Z lewej strony odchodzą w głąb sceny dwaj żołnierze. Jeden z nich unosi wysoko w górę ramiona, a przed nim zarysowuje się zwarta grupa wojowników uzbrojonych w włócznie, podkreślone białymi blikami na tle górzystego pejzażu. Tuż przy lewej krawędzi kompozycji zza żołnierza wyłania się sylwetka słonia z opuszczoną ku ziemi trąbą, o zadziwiająco niewielkich rozmiarach w zestawieniu z ludzkimi postaciami. Pośrodku drugiego planu wznosi się namiot o smukłej sylwecie, z powiewającą u szczytu chorągwią, na którego tle zarysowuje się niewyraźnie kilka osób. W obrębie sceny widnieje kilka napisów wykonanych przez Norwida ołówkiem i wzmocnionych akwarelą. $\mathrm{Na}$ tarczy, o którą wspiera się leżący mężczyzna, wpisana jest sygnatura $\mathrm{z}$ datą: „C.K. NORWID 1850”, natomiast na kamiennym bloku leżącym w prawym dolnym rogu tytuł: „CASTRA / Annibalis”. Towarzysząca podpisowi data jest stosunkowo najmniej czytelna, zwłaszcza ostatnia cyfra „0” niknie pośród linii rysunku. Jako że Norwid nie skupiał się w swej kompozycji na odtworzeniu szczegółów uzbrojenia kartagińskiej armii, intrygować musi wyraźne zróżnicowanie form żołnierskich hełmów. Niewykluczone, że artysta chciał w ten sposób podkreślić niejednorodny charakter zbrojnych zastępów Hannibala, składających się głównie z najemników: Afrykańczyków, Numidów, Iberów, a także Galów i Italczyków, których łączył we wspólnych zmaganiach autorytet genialnego przywódcy?

7 Zob. J. WARrY, Armie świata antycznego, thum. J. Wajs, konsultacja A. Krawczuk, Warszawa 1995, s. 122. W tym miejscu chciałabym podziękować dr Elżbiecie Lijewskiej za garść spostrzeżeń i wskazówek, dzięki którym mogłam uzupełnić niniejsze omówienie akwareli. 


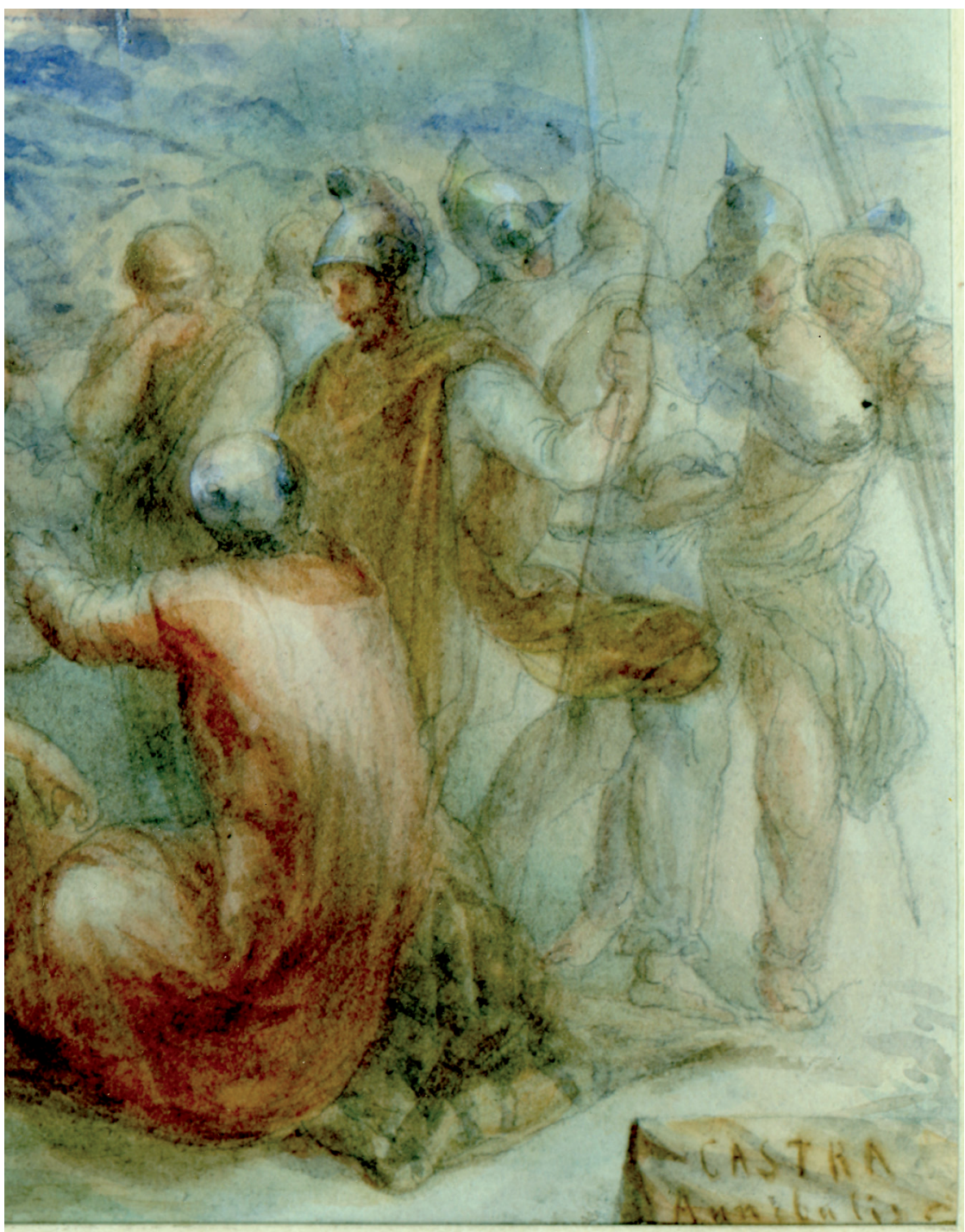

C. Norwid, Castra Annibalis, fragment

Cała akwarela utrzymana jest w niebiesko-czerwono-brązowej kolorystyce, $\mathrm{z}$ akcentami żółci i bieli. Pierwszoplanowa grupa figuralna została wyeksponowana poprzez użycie nasyconej plamy barwnej, podczas gdy pozostałe partie kompozycji, a zwłaszcza boczne fragmenty pola obrazowego, podmalowane są rozcieńczoną farbą, dającą efekt przejrzystego, lekkiego lawowania. Wyróżnione cechy 
techniki akwarelowej, nadto wyraźne podporządkowanie warstwy malarskiej rysunkowi oraz ograniczenie palety barwnej, wspólne są dla wielu Norwidowskich realizacji. Co więcej, Castra Annibalis zdaje się wprost zapowiadać stylistykę późnej twórczości autora Sprzedawcy laurów, dla której charakterystyczna będzie dominacja gęstej akwarelowej plamy, rozlewającej się miękko i zacierającej kontury figur. W ostatnich latach swego życia Norwid ze szczególną atencją zwrócił się ku omawianej technice, chcąc „tam doprowadzić akwarelę, gdzie jeszcze nie była [...] żeby nią swobodnie myśleć można było.". Powstały wówczas takie kompozycje, jak: Opowiadanie, Para w ogrodzie, Zaklęte jezioro (Upiory) czy Chłopiec z drewnianym koniem, ujawniające wypracowanie przez Norwida własnego, odrębnego stylu malarskiej wypowiedzi, pozostającego poza obowiązującymi wówczas konwencjami. Utrzymane w mrocznej, dalekiej od realistycznego odwzorowania, kolorystyce akwarele te zdają się być wizyjnymi scenami, sytuującymi się na pograniczu rzeczywistości i sennego marzenia. ${ }^{9}$ Wprawdzie interesująca nas kompozycja, która powstała niemal ćwierć wieku wcześniej niż wymienione dzieła, przedstawia scenę silnie naznaczoną rodzajowym konkretem, tym niemniej poprzez szereg zabiegów artystycznych, m.in. przez rezygnację ze szczegółowego, precyzyjnie wykreślonego rysunku na rzecz ulotnego szkicu oraz swobodnie potraktowaną warstwę malarską, ewokuje podobną atmosferę tajemniczości i niedopowiedzenia.

Dlaczego Norwid zdecydował się przywołać w tytule swej akwareli imię kartagińskiego wodza? Dlaczego to właśnie jego armia stała się obiektem zainteresowania artysty? Wprawdzie Hannibal nie należy do postaci historycznych wyjątkowo często przywoływanych przez Norwida na kartach jego pism, to można wskazać kilka istotnych nawiązań do jego osoby w twórczości autora Promethidiona. Aż dwukrotnie Norwid użył w funkcji motta do swych utworów cytatu zaczerpniętego z Żywotów wybitnych mężów Corneliusa Neposa, przynoszącego słowa Hannibala, dotyczące młodzieńczej przysięgi, zobowiązującej go do walki z Rzymem. W rapsodzie Niewola czytamy: „Id ego jusjurandum patri datum usque ad hanc diem ita servari, ut nemini dubium esse debeat, quin reliquo tempore eadem mente sim futurus" (Przysiędze tej, danej ojcu, pozostałem tak wierny do dzisiaj, iż nikt nie powinien wątpić, że dochowam jej także w przyszłości) ${ }^{10}$. Tekst Bema pamięci żałobnego-rapsodu inicjuje skrócona wersja powyższej wy-

${ }^{8}$ List do F. Duchińskiego z 22 lutego 1883, PWsz X, 197.

9 Zob. J. ZIELIŃSKI, Malarstwo, niedoceniona twórczość Norwida, „Życie i Myśl” 1962, nr 3-4, s. 168-174; E. ChLebowsKa, Norwid sztukmistrz nieznany, Lublin 2013, s. 276-280.

${ }^{10}$ DWsz IV, 44. Zob. objaśnienia edytora, tamże, s. 289-290. Przekład łac. cytatu na jęz. polski za: K. Nepos, Żywoty wybitnych mężów, tłum. J. Axer, Warszawa 1974, s. 168. 
powiedzi, ograniczona do pierwszej partii przytoczonego zdania ${ }^{11}$. Upraszczając na potrzeby sygnalnego odwołania sensy zawarte we wskazanych mottach, można zauważyć, że Hannibal jawi się w świetle powyższych słów nie tylko jako genialny wódz i strateg, nieustraszony wojownik, ale nade wszystko jako wzorzec wszelkich cnót z wiernością wobec złożonych przysiąg i zobowiązań na czele. W podobnym kontekście przywołał sylwetkę kartagińskiego przywódcy Roger, bohater Nocy tysiącznej drugiej, który w rozpoczynającym akcję komedii monologu zestawił własną postawę życiową z bojową determinacją Hannibala, przekraczającego Alpy w drodze do Rzymu. ${ }^{12}$ Warto zwrócić uwagę, że wszystkie wymienione dotychczas utwory powstały na przełomie lat 40. i 50. XIX stulecia, a ostatni z nich, analogicznie do interesującej nas akwareli, opatrzony został przez autora roczną datą 1850 .

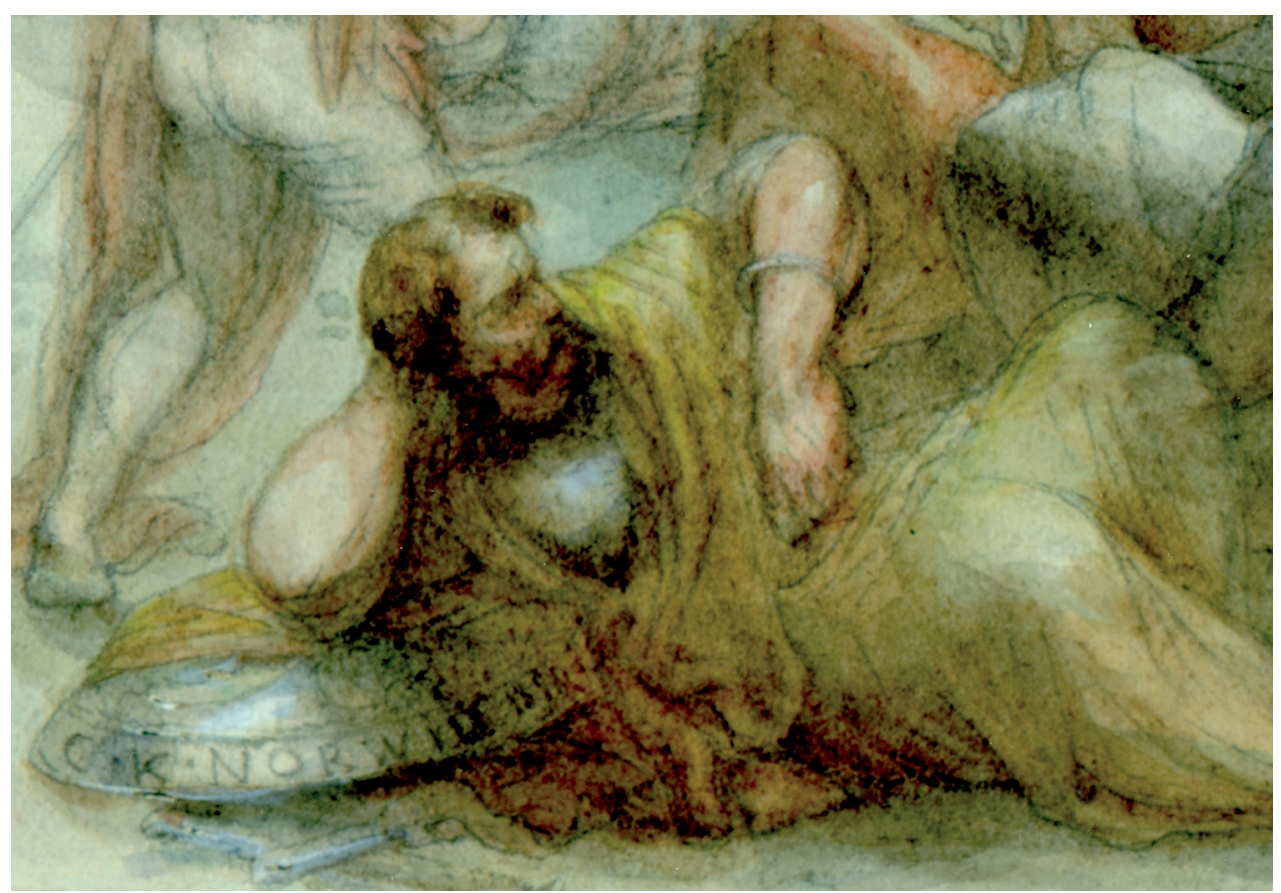

C. Norwid, Castra Annibalis, fragment

${ }^{11}$ PWsz I, 186. Zob. także komentarz J.W. Gomulickiego (w: C. NoRwid, Dzieła zebrane, Warszawa 1966, t. II, s. 411-412) oraz omówienie obu mott w książce M. KARAMUCKIEJ, Antyczny Rzym Norwida, Poznań 2016, s. 432-433.

12 DWsz V, 106. 
Można zatem przypuszczać, że okres następujący po wydarzeniach Wiosny Ludów, które skłoniły Norwida do nagłego opuszczenia ogarniętego rewolucyjnym wrzeniem Rzymu i przeprowadzki do Paryża, przyniósł szczególnie intensywne zainteresowanie poety osobą Hannibala. O tym, że nie było to spojrzenie bezkrytyczne, skupione wyłącznie na gloryfikacji militarnych dokonań wodza przekonuje nas kolejny utwór, w którym przywołane zostało imię Kartagińczyka, a mianowicie artykuł poświęcony problematyce zemsty, opublikowany przez Norwida na początku 1851 r. na łamach „Gońca Polskiego". ${ }^{13}$ Kontynuując linię zdecydowanego moralnego sprzeciwu wobec idei zemsty, będącej siłą „,bezbożną i plamiącą Ducha Narodu" ${ }^{14}$, czemu dał już wcześniej wyraz w monologii Zwolon, pisarz dowodził wówczas, że: „Po uczuciu zemsty, chociażby w piersiach tak skalistych jak Annibala piersi, następować musi osłabienie, bo nasienie zemsty liścia w sobie ani kwiatowego węzła nie ma, ani może dać drzewa z korzeniami, lecz wykorzenienie i perzynę" (Z pamiętnika [o zemście]; PWsz VII, 41). Zawarte w artykule rozważania, poprzez które włączał się Norwid w dyskusję nad problematyką walki narodowowyzwoleńczej, a zwłaszcza kwestią powstań narodowych, stanowią wyraz silnie uwewnętrznionej postawy autora Niewoli, stawiającej ponad wszystko wartości chrześcijańskie, wobec których walka utrzymana w pogańskiej aurze zemsty, budziła bezkompromisowy opór. ${ }^{15}$ Krytyka ,annibalicznego wybiegu" (PWsz VII, 42) nie zdominowała jednak, jak można sądzić, Norwidowskiego sądu o Hannibalu. Wszak po latach, na kartach monumentalnego Albumu Orbis, gromadzącego ,zbiór motywów obejmujący od początku cały przebieg cywilizacji świata", nad którym Norwid pracował od lat 60. niemal do końca swego życia, znalazł się kilkustronicowy blok materiałów poświęconych sylwetce kartagińskiego wodza. ${ }^{16}$ Pierwsza księga ,artystycznego portfela” przyniosła aż trzy wizerunki Hannibala: miedziorytnicze popiersie autorstwa Ambroise'a Tardieu (k. 83 verso), ilustrację przedstawiającą rzeźbiarskie popiersie w profilu podpisane: „Lorichow sc.” (k. 84 verso) oraz wycinek encyklopedycznego hasła

13 1851, nr 29 (z 5 lutego). Zob.: Z pamiętnika [o zemście], PWsz VII, 40-42.

14 M. GrZĘDZIELSKa, Symbolika „Zwolona”, „Pamiętnik Literacki” 1968, nr. 4, s. 88.

15 Zob. H. SiewIERSKi, Polska wolność romantyczna, „Znak” 1981, nr 7, s. 926-927. Uczony zwraca uwagę, że według Norwida zemsta ,zabijając największą wartość chrześcijaństwa, jaką jest miłość, czyni z wolności »annibaliczny wybieg« i »dżumę dla nieprzyjaciela ludzkości«. Dżuma jest tak samo groźna dla wroga, jak i dla jej nosicieli” (s. 927). Zob. także G. GöMöRI, Norwid o Mickiewiczu - spojrzenie poromantyczne, „Studia Norwidiana” 1: 1983, s. 74.

${ }^{16}$ Zob. P. Chlebowski, Romantyczna silva rerum. O Norwidowym „, Albumie Orbis”, Lublin 2009, s. 392; A. BorowIEC, ,, Album Orbis” Cypriana Norwida jako księga sztukmistrza, Gdańsk 2014, s. 237-241; P. Chlebowski, ,Album Orbis”-problemy z ikonografia, w: P. ChlebowsKi, Polihymnia CN 1, Lublin 2019, s. 208, 224, 225 i in. 
poświęconego Hannibalowi z ilustracją jego marmurowego popiersia odnalezionego w Capui (k. 85 recto). ${ }^{17}$ Dodatkowo, na kolejnej stronicy wkleił Norwid miedzioryt przedstawiający przejście armii kartagińskiej pod wodzą Hannibala przez Rodan, wycięty z XVI-wiecznej włoskiej publikacji na temat historii wojskowości autorstwa Francesco Patriziego. ${ }^{18}$

Poza odautorskim tytułem Castra Annibalis wpisanym w obrębie pracy nie dysponujemy żadnymi świadectwami, odnoszącymi się do omawianej akwareli, umożliwiającymi doprecyzowanie jej tematu. W dziejach malarstwa europejskiego zbrojne działania kartagińskich wojsk doczekały się bogatej ikonografii, obejmującej przede wszystkim obrazy ilustrujące sceny bitew (nad rzeką Ticinus, nad jeziorem Trazymeńskim, pod Kannami, pod Zamą, o Nową Kartaginę) i oblężeń (Sagunto, Syrakuzy), dopełnione obrazami przemarszu wojsk (przejście przez Rodan oraz przez Alpy). Norwid nie podjął się przedstawienia jakiejkolwiek sceny bitewnej, związanej z licznymi kampaniami Hannibala, zwłaszcza wojnami z Rzymem. Górzysta sceneria mogłaby wskazywać na morderczą przeprawę przez Alpy, która dała taktyczną przewagę kartagińskiej armii nad wojskami rzymskimi dowodzonymi przez Korneliusza Scypiona w trakcie działań wojennych w 218 r. przed Chr. i utrwaliła na wieki na kartach historii wojskowości ów słynny manewr. Z kolei tytuł akwareli przywołuje na myśl Castra Hannibalis, fort lub port wzmiankowany przez Pliniusza Starszego, położony nad Zatoką Squillace w Bruttium (obecnie Kalabria), którego nazwa miała się wywodzić od ufortyfikowanego obozu Hannibala z ostatnich lat drugiej wojny punickiej. Obecność Hannibala na tym terenie nie została jednak potwierdzona, nie jest również znane dokładne usytuowanie obozu. ${ }^{19}$ Niewykluczone, że Norwid nawiązał w swej akwareli do wspomnianej lokalizacji, przedstawiając wojska kartagińskie z okresu, gdy po paśmie spektakularnych zwycięstw nad Rzymianami musiały zmierzyć się z goryczą porażki, co zarazem korespondowałoby z ówczesnymi przemyśleniami poety zawartymi w tekście $Z$ pamiętnika [o zemście]. W pierwszoplanowej grupie żołnierzy możemy wprost dostrzec objawy pewnego osłabienia czy przesilenia, a szczególnie znacząca wydaje się w tym kontekście wyeksponowana w lewym dolnym rogu kompozycji figura brodatego żołnierza w półleżącej

${ }^{17}$ M. Lachartre, Nouvelle Encyclopédie Nationale, Paris 1870, s. 401-402. Na odwrocie wycinka znajduje się artykuł dotyczący przeprawy wojsk Hannibala przez Wielką Przełęcz św. Bernarda w Alpach. Za: P. CHLeBowsKi, ,Album Orbis” - problemy z ikonografia, s. 208.

${ }^{18}$ F. PATrIZI, Paralleli militari... ne' quali si fa paragone delle milizie antiche, in tutte le partii loro, con le moderne, Rome 1595, tabl. VI po s. 374. Za: P. ChLEBowski, „Album Orbis” - problemy z ikonografia, s. 225.

${ }_{19}$ W. SмIтH, Dictionary of Greek and Roman Geography, t. 1, Londyn 1854, s. 562-563. 
pozie, wspartego na tarczy. Został on ukazany bez nakrycia głowy, a szlachetne rysy jego twarzy, oddane ze szczególną troską mogą budzić przypuszczenie, że jest to wizerunek samego wodza. Hipotezy tej, choć stawianej tutaj ze sporą dozą ostrożności, nie wyklucza analiza porównawcza tegoż wizerunku z innym portretami Hannibala. Mowa nie tylko o wzmiankowanych ilustracjach wklejonych przez Norwida na karty Albumu Orbis, ale również o jednym z najsłynniejszych przedstawień kartagińskiego wodza z epoki nowożytnej, a mianowicie o marmurowym posągu dłuta Sebastiana Slodtza, który do 1872 r. znajdował się w ogrodach Tuileries w Paryżu. Gdyby przyjąć zarysowany trop identyfikacyjny, można byłoby jeszcze ściślej powiązać akwarelę z Norwidowskimi rozważaniami o zemście, uznając tym samym, że Castra Annibalis przynosi wizerunek przywódcy, w którego „skalistych piersiach" nastąpiło już wspomniane przez autora Promethidiona „osłabienie” po uczuciu zemsty.

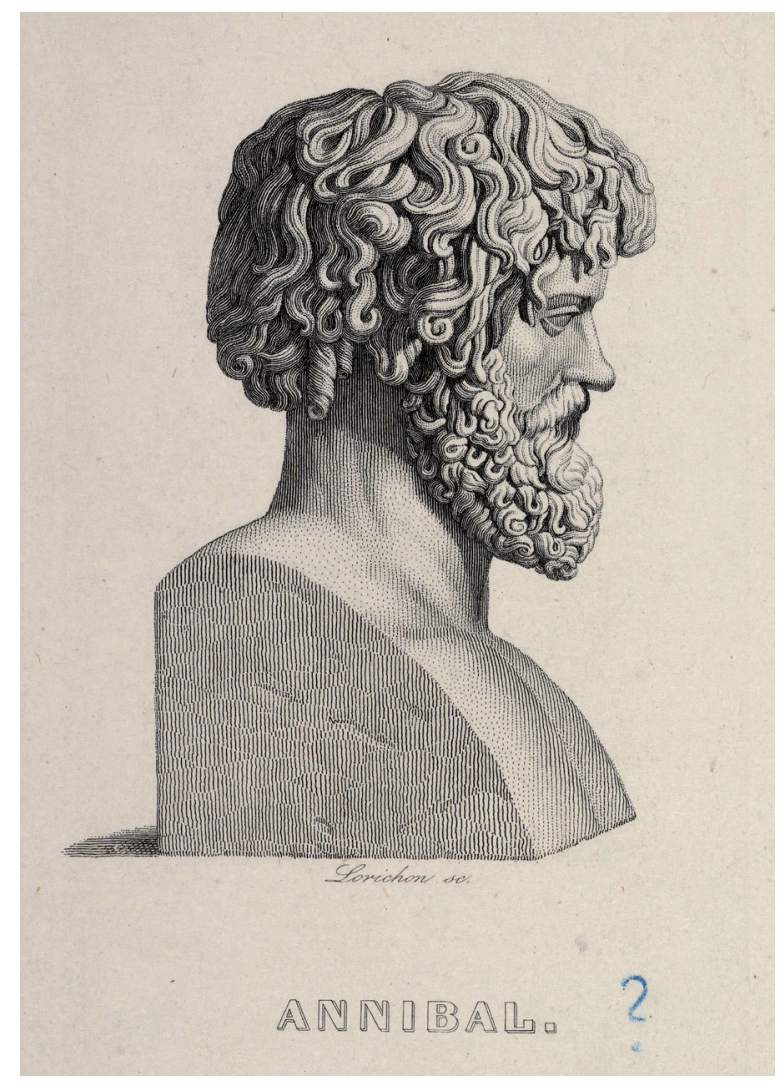

C.L.A. Lorichon, Annibal, rycina wklejona przez Norwida do Albumu Orbis I, k. 84 v., Biblioteka Narodowa 


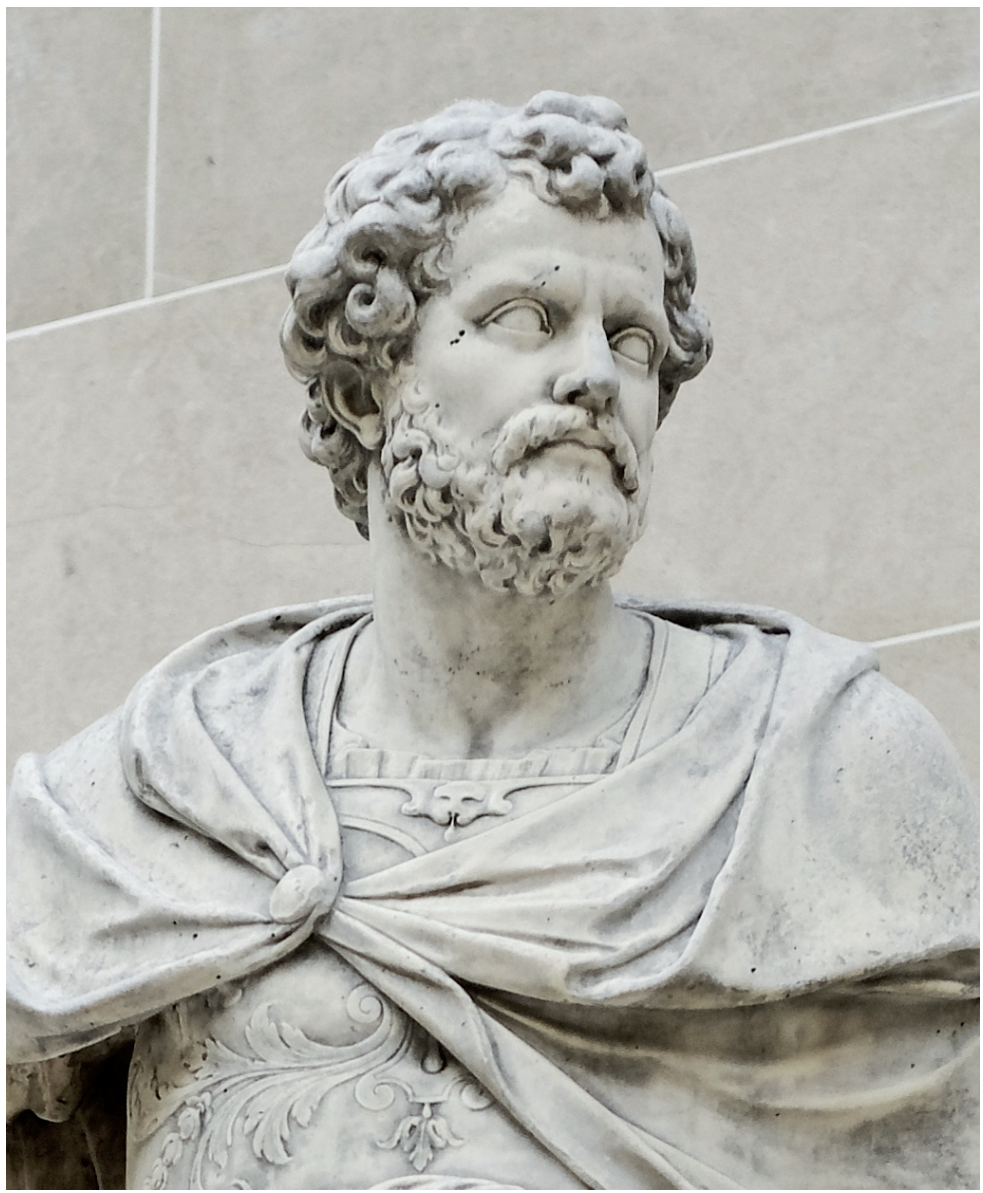

S. Slodtz, Hannibal liczący pierścienie rzymskich żotnierzy

poległych w bitwie pod Kannami, 1704, marmur, Luwr, Paryż, fragment

Niezależnie od tego, której z powyższych sugestii damy pierwszeństwo, warto podkreślić, że wybór epizodu nie związanego bezpośrednio z żadną zbrojną potyczką pozwolił Norwidowi - w zgodzie z jego artystyczną wrażliwością - na przedstawienie prozaicznych kulisów zmagań wojennych, zamkniętych w banalnej rzec by można scenie, utrwalającej jeden z nieskończenie wielu momentów składających się na obozową codzienność. Rezygnacja z patosu i wzniosłości, natomiast skupienie na sytuacjach pobocznych, pozostających poza sferą wielkich czynów, dramatycznych wydarzeń czy nagłych zwrotów akcji, stanowi jedną z charakterystycznych cech nie tylko Norwidowskiej plastyki, ale także twórczości literackiej autora Tajemnicy lorda Singelworth. To właśnie w pozornie mało 
istotnych, kameralnych scenach poszukiwał on bowiem prawdy o człowieku, stąd często bohaterami swoich dzieł czynił „zwyczajnych ludzi”, a perspektywa sługi czy przechodnia była dla niego nie mniej znacząca niż głównego bohatera utworu. Wobec powyższych spostrzeżeń nie powinno dziwić, że Norwid ukazał żołnierzy kartagińskiej armii, a być może również samego jej przywódcę, w sytuacji dalekiej od bojowego zamętu. Epizod ujęty w spontanicznie kreślonym szkicu lawowanym akwarelą stanowi, jak się wydaje autorską wizualizację wojennych realiów, ujętych w kameralną scenę o charakterze niemalże rodzajowym.

\section{BIBLIOGRAFIA}

Borowiec A., ,, Album Orbis” Cypriana Norwida jako księga sztukmistrza, Gdańsk 2014. Chlebowska E., Norwid sztukmistrz nieznany, Lublin 2013.

Chlebowski P., Romantyczna silva rerum. O Norwidowym „Albumie Orbis”, Lublin 2009.

Chlebowski P, ,Album Orbis”- problemy z ikonografia, w: P. Chlebowski, Polihymnia CN 1, Lublin 2019.

Cyprian Norwid. Wystawa w 125 rocznice urodzin. Katalog, Muzeum Narodowe w Warszawie, Warszawa 1946.

Eckhardtówna J., Norwidiana wielkopolskie, „Kronika miasta Poznania”, XX: 1947, nr 2-3, s. 172-177.

GöмÖRI G., Norwid o Mickiewiczu - spojrzenie poromantyczne, „Studia Norwidiana” 1: 1983, s. 71-80.

GrZĘDZIElska M., Symbolika „Zwolona”, „Pamiętnik Literacki” 1968, nr 4, s. 81-96.

Karamucka M., Antyczny Rzym Norwida, Poznań 2016.

MelbechowsKa-Luty A., Sztukmistrz. Twórczość artystyczna i myśl o sztuce Cypriana Norwida, Warszawa 2001.

Siewierski H., Polska wolność romantyczna, „Znak” 1981, nr 7, s. 915-927.

Zieliński J., Malarstwo, niedoceniona twórczość Norwida, „Życie i Myśl” 1962, nr 3-4, s. 168-174.

\section{CASTRA ANNIBALIS}

\section{Streszczenie}

Artykuł przynosi prezentację oraz omówienie nieznanej akwareli Cypriana Norwida Castra Annibalis z r. 1850, przedstawiającej obóz kartagińskich wojsk z czasów drugiej wojny punickiej. Akwarela eksponowana była w 1947 r. w Muzeum Wielkopolskim w Poznaniu na wystawie zorganizowanej w 125 . rocznicę urodzin Norwida. Ówczesnym właścicielem obiektu był historyk literatury polskiej prof. Roman Pollak.

Słowa kluczowe: Cyprian Norwid; Hannibal Barcas; druga wojna punicka; akwarela; malarstwo historyczne. 


\title{
CASTRA ANNIBALIS
}

\begin{abstract}
The article presents and discusses the unknown watercolour of Cyprian Norwid „Castra Annibalis" from 1850, which represents the Carthaginian military camp from the times of the Second Punic War. The watercolour was exhibited in 1947 in the Museum of the Greater Poland in Poznan at the exhibition organised for the 125th anniversary of the birth of Norwid. At that time, the owner of the piece swas the historian of Polish literature, professor Roman Pollak.

Translated by Salomea Chlebowska
\end{abstract}

Key words: Cyprian Norwid, Hannibal Barca, the Second Punic War, watercolour, history painting.

Edyta Chlebowska - doktor, historyk sztuki, adiunkt w Ośrodku Badań nad Twórczością C. Norwida KUL; e-mail: edyta.chlebowska@kul.pl 